\title{
Reforming Juvenile Justice in Nineteenth-Century Scotland : The Subversion of the Scottish Day Industrial School Movement
}

\section{Christine Kelly}

\section{(2) OpenEdition \\ Journals}

Electronic version

URL: http://journals.openedition.org/chs/1670

DOI: $10.4000 /$ chs. 1670

ISSN: 1663-4837

Publisher

Librairie Droz

\section{Printed version}

Date of publication: 1 December 2016

ISBN: 978-2-600-01953-8

ISSN: 1422-0857

\section{Electronic reference}

Christine Kelly, «Reforming Juvenile Justice in Nineteenth-Century Scotland: The Subversion of the Scottish Day Industrial School Movement », Crime, Histoire \& Sociétés / Crime, History \& Societies

[Online], Vol. 20, n² | 2016, Online since 01 December 2018, connection on 04 May 2019. URL : http:// journals.openedition.org/chs/1670; DOI : 10.4000/chs.1670

\section{This text was automatically generated on 4 May 2019.}

(c) Droz 


\title{
Reforming Juvenile Justice in Nineteenth-Century Scotland : The Subversion of the Scottish Day Industrial School Movement
}

\author{
Christine Kelly
}

1 This account examines the origins and development of fresh initiatives to respond to juvenile offending in Scottish cities from the mid-nineteenth century, exploring matters from a legal historian's viewpoint. The Scottish contribution in the field of juvenile justice reform has been somewhat neglected by historians but its impact was significant and far reaching, extending throughout the UK, and even as far afield as Australia. ${ }^{1}$ It was widely appreciated well into the twentieth century that the Scottish system provided the template for industrial schools throughout Britain. As the influential English Report of the Departmental Committee on the Treatment of Young Offenders of 1927 observed in reviewing the history of schools and institutions for young offenders in England, the Scottish day industrial schools "may be regarded as the parents of the industrial schools." ${ }^{2}$ Despite this wide-reaching influence, the origins of reform began humbly, with local, philanthropically-inspired responses to juvenile offending. The article will focus particularly on the inception and adoption across Scotland of a network of day industrial schools, also known as Industrial Feeding Schools, first introduced by Sheriff William Watson in Aberdeen in the 1840s. It examines the underlying changes taking place in administration of criminal justice which facilitated this development. The paper goes on to discuss the creation of a national British statutory system of certified industrial and reformatory schools, arguing that the predominantly disciplinary character of these schools ultimately subverted the welfarist ethos on which the locally founded Scottish schools were based.

2 An important aspect to emphasise here is the impact of the trend towards centralisation. This was a recurring theme in nineteenth century criminal justice, reflecting the transition from local, ad hoc systems to national forms of organisation which has been 
well identified by a number scholars such as Lindsay Farmer, David Barrie and Susan Broomhall in areas ranging from criminal procedure to policing history. ${ }^{3}$ A similar shift from local to national systems occurred in relation to diversionary approaches for young offenders in Scotland and it is suggested that this process saw the largely disciplinary focus of the English reformatory movement gain ground at the expense of the defining welfarist ideals of the Scottish day industrial school movement. In other words, the resultant British statutory system was marked by a different, more punitive approach which departed considerably from the ethos of the original Scottish system of day industrial schools. This is not to suggest, though, that there is necessarily a stark dichotomy between welfarist and punitive systems. As Donzelot, Cox and Mahood all recognise, in practice matters are far more nuanced: ostensibly contrasting approaches each contain ambivalent elements that can be characterised as controlling, disciplinary and protective. ${ }^{4}$ As will be discussed here, this inevitable conflict was all too apparent both within the practice of some Scottish schools and within the English reformatory movement with its wide spectrum of views encompassing both the idealist humanitarian Mary Carpenter and the more retributively minded Sydney Turner and Barwick Lloyd Baker. $^{5}$

One of the most striking aspects of this account is the degree of contact and co-operation between those involved in reform movements in different countries. This applied most obviously in the British context with the longstanding connection between the eminent English reformer, Mary Carpenter, and the leading Scottish reformer, Sheriff William Watson. In his autobiography Watson recorded that he had "long corresponded" with her [Carpenter], speaking of her "energy" and saying that she was "held in great respect by all philanthropists." Mary Carpenter was extremely impressed by Watson's efforts in Aberdeen, commending his successes to a Select Committee in 1852 and even basing her proposed scheme for industrial schools on Watson's model of day feeding schools. ${ }^{7}$ Mary Carpenter's co-reformer Matthew Davenport Hill, the Recorder of Birmingham, held Watson in similarly high regard, as will be discussed later. But the interjurisdictional influences extended even further. They were evident on an international scale.

The effects of profound and rapid industrialisation, displacement, economic and social change were features affecting the youth of many European countries as well as the US. These changes provided a powerful incentive to reformers of juvenile justice who were eager to exchange new ideas about the best ways to approach reform. This opened up new channels of cross-border communication with reformers being influenced by new experiments developed elsewhere. For instance, as a committed Unitarian, Mary Carpenter looked to her co-religionists in New England for inspiration on reformatory institutions being introduced there. ${ }^{8}$ Perhaps most influential of all was the pioneering disciplinary model of the Mettray institution for young offenders established near Tours in France in 1840 by Frédéric-Auguste Demetz. Soon similar reformatory agricultural colonies run on family lines were being set up by philanthropists in many other European countries, such as the Rauhe Haus near Hamburg. ${ }^{9}$ Mettray was much admired by the English reformatory movement, providing the model for the Philanthropic Society's reformatory institution at Red Hill in Surrey in 1849 where the formidable Rev. Sydney Turner was chaplain before his appointment as first Inspector of Reformatory and Industrial Schools. ${ }^{10}$ The French influence was also important in the Scottish context : the section of the Code Pénal referring to children under the age of sixteen being presumed to act sans discernement was discussed in a book by Watson's fellow reformer Alexander 
Thomson in $1852 .{ }^{11}$ It was also noted by Sydney Turner in one of his Inspector's reports. ${ }^{12}$ Even more significantly for the Scottish history, a school very similar to Mettray appeared near Edinburgh in 1859 in the shape of Wellington Reformatory Farm School. ${ }^{13}$ of course this inter-jurisdictional influence continued to be a feature of criminal justice reform throughout the remainder of the century and beyond, with later developments such as the introduction of juvenile courts and probation.

5 As Heather Shore and Pam Cox have shown, certain discourses and themes regarding troublesome youth have been a recurrent theme in different contexts, places, countries and over varying time spans. ${ }^{14}$ For instance, Cat Nilan's analysis of the trials of child criminals in the French legal journal La Gazette des Tribunaux, 1830-1848, reveals many of the same themes concerning youth offending which are apparent in the city of Aberdeen in the $1840 \mathrm{~s} .{ }^{15}$ These include the role of parental (ir)responsibility, pity for vagrant children, philanthropic intervention, the discomfiting of the judiciary and the notion of the corrupting influence of criminal activity. It appears that the problems identified in Aberdeen and the responses to them were not unique. As Shore and Cox also rightly point out, searching for the 'invention' or 're-invention' of delinquency at specific junctures is beset with the problem that similar patterns of disorderly behaviour and regulatory responses can be identified in the seventeenth century as well as the nineteenth. ${ }^{16}$ Nonetheless, the evidence presented here on Aberdeen does strike a definite chord with Susan Margarey's work on The invention of delinquency in early nineteenth-century London, where she identifies the criminalising impact on children of a combination of summary processes and changes in legislation. ${ }^{17}$ Arguably these factors were a very significant factor in early nineteenth-century Scotland too. ${ }^{18}$ As Shore argues in Artful Dodgers, while it may be problematic to suggest a wholesale 'invention of delinquency' in this period, it is true that the early nineteenth century has "come to be seen as something of a watershed because of its coincidence with the striking social, economic and political changes that were occurring." 19 The special significance of the nineteenth century for the public focus on juvenile crime has been underlined by a number of other important studies too. These include Margaret May's work emphasising the role of intensive inquiries and investigations in highlighting the issue as well as, of course, the highly influential work of Radzinowicz and Hood which argues that the concept of the young offender is a Victorian creation. ${ }^{20}$ May's observation on the growth in literature on juvenile crime is borne out in this account in the literature referred to here on the subject of juvenile vagrancy and juvenile offending written by those involved in the Scottish and English reform movements.

6 It is also worth pointing out that the developments discussed in this paper resonate with the findings of other scholars too. This applies particularly to Peter King's research on the role of diversionary practices for young offenders in London. ${ }^{21}$ King's work on the London Refuge for the Destitute uncovers the new diversionary sentencing policies pursued by Old Bailey judges and magistrates in the first three decades of the nineteenth century. These saw judgement respited and young offenders directed instead to the reformatory establishment The Refuge for the Destitute. King shows how the initial focus of the Refuge was on both the destitute and the criminal, but this changed over time as it evolved into a reformatory establishment catering for young offenders. King argues that as the Refuge had no legal authority to detain inmates against their will, its transition to a secure prison-type institution meant that it operated on the fringes of legality. The Refuge appears to have been remarkably successful in advancing its own position as it 
was the only one of the three early reformatory establishments in early nineteenthcentury England which attracted state funding. The other two, the Philanthropic and the small asylum at Stretton on Dunsmore, were reliant on philanthropic support. Although Shore points out that the overall impact of these early voluntary initiatives was fairly limited, ${ }^{22}$ the active role of the judiciary in formulating and implementing new diversionary practices for young offenders has definite parallels with the situation in Scotland presented in this paper.

7 While there has been much scholarly work on the English situation, sadly, the existing historiography on Scotland is far less extensive. I should point out that most of the contemporary scholars mentioned in the references have written on the English history with the exception of Lindsay Farmer's important book on Scots criminal law, Linda Mahood's and Barbara Littlewood's work on Scottish child savers, Linda Mahood's sociological study of institutions for young offenders and Andrew Ralston's article on Scottish industrial and reformatory schools. ${ }^{23}$ Mahood and Littlewood are particularly significant in this context in emphasising the disciplinary nature of child saving interventions. This point is also reinforced in the English context by Pamela Cox and Michelle Cale who, like Mahood, stress the highly gendered nature of the regulation of young offenders, especially in relation to the sexual policing of girls. ${ }^{24}$

Overall, until recently, there has been a surprising dearth of scholarship which places a direct focus on the Scottish dimension, especially on the complex detail of the legislative developments involved and their application by the courts. This is a subject I have addressed more fully elsewhere. ${ }^{25}$ Encouragingly, although in general the Scottish aspect has been rather overlooked, there has recently been a new flourishing of interest in the Scottish history with the publication by Susan Broomhall and David Barrie on Scottish police courts, as well as work on theme of continuity and change in the history of Scottish juvenile justice. ${ }^{26}$ My hope is that this article will contribute to this growing interest on the subject

9 The paper proceeds by looking at the political, legal and social context in which the Scottish reform movement began. It then examines the diversionary schemes responding to juvenile offending, beginning with a scheme unique to Glasgow and then moving on to focus on the day industrial school movement which was implemented in most large Scottish towns by the 1850 s.

\section{The political, legal and social context of the changes}

10 It is striking that some of those most involved in attempting to bring about change in ways of dealing with juvenile offenders in Scotland were the judges before whom young offenders appeared, especially Sheriffs. Foremost among the innovators in this area were Sheriff Watson of Aberdeen and, to a lesser degree, Sir Archibald Alison, the Sheriff of Lanark, who is better remembered in Scotland as a writer on Scots Criminal Law than as a juvenile justice reformer. ${ }^{27}$ Sheriff Hugh Barclay of Perth was also active in the reform movement, authoring a book on juvenile delinquency and helping to draft the earliest Scottish legislation on industrial schools. ${ }^{28}$

11 Sheriffs such as these occupied a powerful position, both legally and politically, and those of a reforming disposition had an ideal platform from which to introduce their innovative ideas. In the wake of the Jacobite rebellion of 1745 an administrative and legal framework 
was put in place to draw previously feudal jurisdictions into the control of the Crown through the creation of a hierarchy of Sheriff and Justiciary Courts. ${ }^{29}$ Sheriffs were at the centre of this system. They were legally qualified judges who oversaw the first instance courts. They had to reside in their sheriffdoms for at least four months a year, charged with supervising the administration of justice in a system where crimes were prosecuted by public prosecutors.

12 It was within this context that innovators such as William Watson and Archibald Alison and were able to operate so effectively. Presented regularly with the large numbers of children repeatedly appearing before local courts for minor offences such as begging, breach of the peace or trivial thefts ${ }^{30}$, many judges felt disheartened $:^{31}$ Imprisonment of children exposed them to contaminating influences, it was regarded as futile in terms of deterrence and it stigmatised the children for life, rendering them almost unemployable. In Aberdeen and Glasgow in particular Sheriffs were instrumental in devising new diversionary schemes to respond to juvenile offending. But the reform movement was not only composed of judges : it also embraced others who were active in civic life, most notably the charismatic Edinburgh Free Church Minister Thomas Guthrie, author of the successful publication A Plea for Ragged Schools or Prevention Better than Cure. ${ }^{32}$ Guthrie's involvement underlines the important role of religious belief in driving the schools forward. Indeed the literature of the reform movement is imbued with a sense of the missionary fervour ; its goal to reclaim the lives of marginalized and outcast children. Another important defining characteristic of the movement was the extent to which it was a community enterprise. Not only were pre-statutory schools funded by voluntary contributions from local people, they involved the community in a very practical sense too: this was demonstrated by the admissions procedure in Aberdeen, where the admissions committee for the schools, the Child's Asylum Committee, was composed of representatives from a number of local organizations. This will be discussed later in the paper. This community aspect was also evident in the financing of Glasgow's Houses of Refuge, as will be seen next.

\section{The Glasgow Houses of Refuge under local legislation}

Sheriff Alison in Glasgow was involved in setting up a system of pre-trial diversion for juveniles where a child could opt to become an inmate of a House of Refuge rather than proceed to trial. ${ }^{33}$ This was a system based on local legislation, an Act of 1841 for repressing juvenile delinquency in the city of Glasgow..$^{34}$ Under the Act the costs of the Houses of Refuge (one for boys and another for girls) were met by charging local residents a small sum. This was an appeal to Glasgow's sense of civic responsibility in which it was seen to be in the interests of the local community to fund an enterprise to prevent juvenile offending. In the 1840s some judges from the High Court of Justiciary were making use of this local scheme. ${ }^{35}$ The Act applied where children under twelve were undergoing trial. In cases where the prosecutor consented, and the Board of Commissioners of the House of Refuge agreed, then the child's counsel could ask for proceedings to be discharged. Instead an order would be made for reception into the House of Refuge. There is a reported case from 1845 which shows the system in operation in the trial of three young girls charged with theft by housebreaking. ${ }^{36}$ Two of the girls were sent to the House of Refuge, one for three years and the other for five years; the third girl proceeded with the trial and was sentenced to transportation for ten years. ${ }^{37}$ 
The Act could also be used by children released from the Glasgow prison or bridewell, who had no home to go to. They could make voluntary requests for admission. The idea was that the Refuge would provide them with education and train them in a trade so that they would not fall back into criminal habits. ${ }^{38}$ The Glasgow system based on local legislation was not adopted elsewhere. This contrasted with the Aberdeen day industrial school scheme introduced by Sheriff Watson around the same time, which was widely emulated in other large Scottish towns, including Glasgow, where it operated alongside the Houses of Refuge.

\section{The Aberdeen system : origins of the day industrial school}

Of all the Scottish cities Aberdeen was the cradle of juvenile justice reform in Scotland. It was there that the Scottish industrial school movement first came into being, as the creation of Sheriff William Watson of Aberdeen, who was the leading reformer of juvenile justice in nineteenth century Scotland. Born in 1796 into an affluent farming family in Lanarkshire, Watson was one of eight children. ${ }^{39} \mathrm{He}$ attended Edinburgh Academy and then studied law at Edinburgh University before embarking on an apprenticeship with an Edinburgh firm in 1813. In 1829 he was appointed to the post of Sheriff Substitute of Aberdeenshire. He immersed himself in the civic affairs of Aberdeen, seeking to improve the social conditions of the poor, especially the children of the urban poor. He chaired the Board of Health when there was a threatened cholera epidemic in the town, and was involved in setting up a home for the destitute of all ages in Aberdeen. Most of all he was concerned with the plight of the poorest children and their lack of access to education. He wrote that he could not help but feel guilty punishing children in the exercise of his judicial role for "some unconscious fault" when he had done nothing to help them gain an education..$^{40}$ Like many nineteenth-century philanthropists he was mainly motivated by deep religious conviction. ${ }^{41}$

15 It is important to have some sense of the kind of place Scotland was in the 1840 s. According to one historian, life for the poor was "competitive, unprotected, brutal and, for many, vile." ${ }^{42}$ The demands of increasing industrialisation and rapid population growth were accompanied by the miseries of overcrowding, disease, and squalor, making Scottish cities a hostile environment for the children of the poor. Watson was particularly concerned about the large, transient population of juvenile vagrants..$^{43} \mathrm{He}$ was disturbed by the "cruel" and "absurd" plight of the many young children of this kind appearing before the local courts, many of whom were aged only eight to eleven years of age, but who were repeatedly being imprisoned for minor offences. He found this especially perplexing because "it is known that unless by begging or stealing ninety-nine in a hundred have no way of subsisting." ${ }^{44}$

It is clear from Watson's writings that there were four main factors which contributed to the increasing numbers of children coming before the courts and being imprisoned in Aberdeen. These were changes in criminal procedure, more vigorous policing, the effect of new criminal prohibitions, and the impact of sentencing practices. It is worth looking briefly at each of these factors, which were not unique to Aberdeen, but were replicated on a much broader scale across the country. As noted earlier, these factors emphasised by Watson show parallels with the findings of Susan Margarey on the invention of juvenile 
delinquency in early nineteenth-century London in relation to the combined effect of criminalising legislation and summary processes.$^{45}$ It appears that significant changes in criminal administration had far reaching consequences for children both in Scotland and England.

Firstly there was the effect of summary procedure on young offenders. From 1828 onwards, summary procedure was widely used to allow lower courts to deal quickly and simply with offences ${ }^{46}$ In Scotland there is clear evidence to show that under summary procedure children appeared before the courts much more frequently than before. ${ }^{47}$ This created the illusion of an increase in juvenile crime. For example, the 1843 report by the Governor of Aberdeen prison discussed the causes of an increase in commitments of boys under the age of twelve and was very critical of the impact of summary procedure which he blamed for the repeated trial of young offenders and the repeated imposition of short sentences of imprisonment. To illustrate this, he gave the example of an eleven year old boy who in the space of three years had received five sentences of imprisonment for theft, the last of which was for fourteen days and one for vagrancy for twenty days. ${ }^{48}$ So, it appears that the availability of fast procedure encouraged prosecution of trivial offences, and children were repeatedly processed rapidly through the courts and subjected to short-term sentences of imprisonment. This created an escalating momentum in the volume of offenders. ${ }^{49}$

18 Secondly there was the effect of very active policing. Watson wrote about a local Police Act for Aberdeen coming into operation in 1829 which set up a regular police force, greatly increasing the level of law enforcement. ${ }^{50}$ The third factor was the effect of new offences created under this Police Act..$^{51}$ Watson described these as offences which no-one had ever heard of before. The types of offences he was talking about here were new minor offences designed to impose order and control behaviour in public spaces, a common feature of urban regulation at this period as cities responded to the challenges of growing population associated with industrialisation. ${ }^{52}$ The offences which particularly affected children related to activities normally carried on by children as a matter of course as they played outdoors, but there were other offences which applied more generally such as a prohibition on beating carpets after eight o'clock in the morning. Under this legislation the offences carried a penalty of a fine of a few shillings or a few days' imprisonment. Watson was severely critical of this new form of criminalization :

We call those acts injurious which are wilfully injurious to person or property. Flying a kite, throwing a snowball or sliding on the ice for which children by local police acts or provisional orders may be sent to prison, though abundantly annoying, can hardly be called crimes. ${ }^{53}$

19 The fourth factor was inconsistency of sentencing in the justice of the peace and police courts, which Watson attributed to the judges in these courts not having any legal training. ${ }^{54}$ This meant that offenders could face considerable penalties for infringing these new prohibitions. He said that while one judge might impose a fine of half a crown or five days imprisonment another might for the same offence impose a fine of twenty shillings or twenty days, with or without hard labour. Watson described prisons filled with men, women and children of all ages sentenced by burgh magistrates to short periods of imprisonment for breaching the new offences. The punishment extended beyond imprisonment as those sentenced to imprisonment were socially ostracized : they could not find work as employers would refuse to employ them. Watson attempted to help those affected by holding a meeting with several manufacturers in July 1838 to persuade them to hire ex-prisoners but they refused because other employees, especially 
women, would not work alongside them. ${ }^{55} \mathrm{He}$ was so disillusioned by all of this that he wrote that if someone set out deliberately to "pauperise" and "demoralise" the poor and "increase the number of delinquents" then the most effective way of doing it would be by making "harmless acts" into police offences. ${ }^{56}$

By the early 1840s Watson was becoming increasingly frustrated and determined to act. The scheme he had in mind centred on his idea of an industrial school to be paid for entirely from voluntary contributions. It is important to recognize that in this period there were a great many children not attending any kind of school. Some indication of the scale of educational deprivation in the mid nineteenth century is provided by looking at the Second Report of the Argyll Education Commission on Elementary education in Scotland (xxv-xxvi), which reported in 1867, five years before the introduction of compulsory education in Scotland :57 the Commission found that there were 5,000 schools engaged in elementary education with 400,000 pupils but there were 90,000 children with no access to education..$^{58}$

Watson had previously been involved in education for the poor as president of the Education Society. He had also formed a Society for Promoting Education among the Poor. The parish schools which existed in Watson's time required payment of a small fee which the very poorest could not afford, and his society offered these children a free ticket to attend school to be renewed after three months if attendance was satisfactory. ${ }^{59}$ This earlier idea had proved ineffectual because the children were too ragged and hungry to attend and were often refused admittance to schools attended by poor children of a more respectable class. An article in Household Words, edited by Charles Dickens, observed that these were the sort of children who had "a raggedness and dirtiness which defied classification, and demanded an establishment of their own." ${ }^{60}$ So this is what Watson set out to provide with the new idea of the industrial school.

\section{The Day Industrial Schools in practice}

The day industrial schools established in Aberdeen in the 1840s were set up for vagrant, destitute children and juvenile offenders who were referred by magistrates instead of being sent to prison. The schools provided food, education and training in a trade. Children were offered three meals a day, instruction in the three Rs, scriptural studies, and practical training in tailoring, shoemaking and the making of salmon nets. ${ }^{61}$ These were the types of skills which were considered useful in securing employment in later life..$^{62}$ The system was supported entirely by voluntary contributions from local people with a school for boys in 1841 followed by one for girls in 1843. The aim was preventive, to rescue the most vulnerable children from a life of crime. No distinction was made between the neglected and the petty offender, both being regarded as children with same types of problems. ${ }^{63}$ The primary goal was the creation of useful citizens, the inculcation of the values of the respectable, sober and industrious and, ultimately, the evangelisation of whole families. The instillation of moral values was seen as the key element in transforming the lives of children whose families lived on the very margins of society. Watson described the role of children in their family circle as being that of "home missionary in homes so wretched the self-regarding missionary would have feared to enter." ${ }^{\prime 64} \mathrm{He}$ saw it as essential to support the family unit and this was why he so strongly disapproved of later developments under the statutory system where children were forcibly separated from their parents. 

attendance of pupils in the absence of legal powers of compulsion. For example, in May 1845 he persuaded his colleagues on the local bench to assist in a scheme to use an old statute prohibiting vagrancy to authorise police to round up seventy-five local children still found begging on the streets and direct them to the premises of an old soup kitchen where a new industrial school was to be established. ${ }^{65}$ There was some dubiety about the legality of this procedure, but Watson overcame the initial reservations of his colleagues. The captured children were told they were not compelled to return but that begging would not be tolerated by the police. The system was also bolstered by the support of the local community, not only a financial level, but in the governance of the schools. In 1846 a Child's Asylum Committee was set up to deal with admissions to the schools and this was made up of representatives from a range of local bodies including the management boards of industrial schools, many of whom were magistrates, along with police representatives, town councillors and poor law officials. In essence this was a genuine civic enterprise, as was recognised by the foremost English reformer of juvenile justice, the reformatory campaigner, Mary Carpenter, when she observed that Aberdeen's Child's Asylum Committee had "effected a social reformation altogether unexampled."66

claimed great success for his project, crediting it with eliminating juvenile vagrancy in Aberdeen. Elated by his achievement, Watson became an ambassador for the system, the "apostle of the industrial school", as he put it. ${ }^{67} \mathrm{He}$ avidly promoted the value of his experiment, advising on its benefits, with the result that his system was adopted by other Scottish towns and cities in the course of the $1840 \mathrm{~s} .{ }^{68}$ This was the high point for Watson. His project was highly praised in a widely published journal in 1845 Chamber's Journal.$^{69}$ His schools were visited by the likes of the author William Thackeray, who was said to be moved to tears by the sight of so many children rescued from a life of crime. ${ }^{70}$ In 1851 Mary Carpenter wrote her internationally distributed book on juvenile offenders ${ }^{71}$ which was full of praise for Watson's success in Aberdeen. And in evidence to the 1852 Select Committee on Criminal and Destitute Juveniles she presented a detailed account of statistics demonstrating the success of the Aberdeen initiative. ${ }^{72}$ Her fellow reformer in the English reformatory movement, the influential judge Matthew Davenport Hill, the Recorder of Birmingham, regarded Watson as being of similar stature to Frédéric-Auguste Demetz, the founder of the celebrated pioneering establishment for young offenders at Mettray in France. ${ }^{73}$ He wrote that, "a Demetz or a Watson, like the poet, nascitur, non fit ; ${ }^{74}$ and yet these men not only do good in their own sphere, but they raise the general average of well-doing." ${ }^{75}$ Even Charles Dickens' popular journal Household Words carried an article referring admiringly to Watson's achievements :

The plan appears to have been strikingly successful; and what magic was there here? Why should the country shudder in a cowardly manner over details of horror- when a little money and a little courage will do so much? Aberdeen has done an act of real charity and good sense here, blessed itself and blessed these poor vagrants. The poor must be taught, somehow, if society means to exist. ${ }^{76}$

By the early 1850s the majority of large Scottish towns had industrial feeding schools based on the Aberdeen model..$^{77}$ While most were named industrial schools, others (particularly in Edinburgh) described themselves as ragged schools. The admissions procedure to the schools in other towns was similar to that in Aberdeen in aiming to restrict attendance to cases of genuine need and refusing admission to those who could claim relief from parish funds under the poor law. In addition to those applying for voluntary admission to the industrial schools, children were referred by the courts. In 
these cases judges sometimes acted under local legislation to authorise children's referral to the schools, as happened in Aberdeen, while in other areas there appears to have been no pretext of legislative authority. ${ }^{78}$ Contemporary accounts attest to the success of the pre-statutory system. For instance Watson's co-reformer, Rev. Thomas Guthrie, spoke about the transformation in Edinburgh. ${ }^{79} \mathrm{He}$ said the streets had almost been cleared of juvenile beggars which was a huge achievement. By 1852 over six hundred children aged between six and fourteen attended the four industrial schools which had been set up in the city in 1847. In that time 200 children had been referred by magistrates instead of being sent to prison.

\section{The statutory system}

But the Scottish reformers wanted more. They wanted to set the system up on a more secure financial footing. To do that they needed government aid. They also wanted judges to have the unequivocal legal power to send children in need to industrial schools. The kind of children they particularly sought to compel to attend were those with profligate parents who had the means to support them, but instead wasted the money on alcohol. The aim was to force these parents to pay towards the cost of their children's education at the industrial schools.

The Scottish reformers joined forces with those active in the English reformatory movement also seeking legislation to tackle juvenile offenders. ${ }^{80}$ Prominent among these were, as previously noted, the Bristol philanthropist, Mary Carpenter ${ }^{81}$ and the judge Matthew Davenport Hill. ${ }^{82}$ But the eventual creation of a national UK legislative framework in time subverted the Scottish system, undermining the original welfarist principles of reform..$^{83}$ This was an insidious process. The early years of the statutory system were marked by a transitional period of adjustment. In essence Scotland and England were approaching the problem from different standpoints. Scotland had a preexisting network of industrial schools based on an inclusive ethos which did not distinguish between the offender and the purely destitute and was firmly rooted in the concept of the day school..$^{84}$ This contrasted with the approach of English reformers which was intent on classifying children in a somewhat utilitarian fashion: the aim was to separate those who been branded by conviction from the vagrant and destitute thought to be in danger of falling into criminality. According to this view, the confirmed criminals, the 'dangerous classes', required reformation in the disciplinary context of residential reformatories while the pre-criminal group, the 'perishing classes', could be catered for in residential industrial schools. ${ }^{85}$ The attempt to merge operations in both countries into one system resulted in a complex web of legislative confusion.

With the arrival of two Acts in 1854 Scotland had a statutory framework in place. ${ }^{86}$ There was the specifically Scottish measure, Dunlop's Act for destitute non-offenders. ${ }^{87}$ There was also an Act applying across Britain, the Youthful Offenders' Act, which empowered courts to send children under sixteen convicted of an offence to a reformatory. ${ }^{88}$ As far as the Scottish reformers were concerned, Dunlop's Act achieved what they had set out to do. The main objectives of the Scottish campaigners were enshrined in the Act: it invested magistrates with the legal authority to compel vagrant or destitute children under fourteen to attend an industrial school under court order, and to force parents who had the means to do so to pay for their child's education. It was designed to cater for the Scottish situation where there was an existing network of pre-statutory schools which 
sought extra powers to compel attendance. The main drawback from Watson's point of view was that the Act introduced the principle of residential attendance for children under court order. Under the pre-statutory system the schools had adhered to the principle of day attendance except in cases of extreme need. Over time the residential system was to effect a major change. Watson greatly disapproved of this. He blamed it for splitting up families, destroying family affection and leaving children with no home to return to. ${ }^{89}$

It is clear that for Watson and the other Scottish reformers the primary focus was always on the preventive role of the industrial school..$^{90}$ Watson saw the English conception of the reformatory for the convicted offender introduced by the Youthful offenders Act as an adjunct to his system which could at best complement it, but not supersede it in any way. Reformatories, in his view, could only be useful in extreme cases where the primary aim of prevention had failed, an opinion forcefully echoed by his fellow reformer Thomas Guthrie. ${ }^{91}$ They were the last resort, almost an admission of failure. In Watson's view there was no real reason to classify children, and Dunlop's Act reflected this: it was framed in such a way that it was clear the intention was that vagrant and offending children would continue to attend the same institutions. All Watson wanted essentially was to have the existing pre-statutory system set up on a stronger financial and legal foundation. This is not what happened.

In the wake of the statutory framework created in 1854 there were strong pressures towards a uniform system north and south of the border. This was accentuated by the creation of a national inspectorate to oversee the schools. By 1857 reformatories for young offenders were being set up in Scotland to operate alongside the industrial schools for the destitute. The reformatories, usually farm schools, were run along the same harshly disciplinarian lines as those established in England..$^{92}$ The ethos was one which insisted on a period of preliminary imprisonment of fourteen days prior to entering the reformatory. This was exactly the opposite of what Watson had wanted. He had wanted to keep children out of prison. Once admitted to the reformatory, the route to reformation was seen to be through very arduous, often back-breaking work. This introduced a highly retributive element ${ }^{93}$ entirely absent from the original welfarist ideals of reform. By the time that the consolidating UK legislation on industrial and reformatory schools appeared in the mid-1860s the statutory system was well entrenched. The industrial schools became institutions to which vagrant, destitute children under fourteen and younger offenders under the age of twelve were admitted under court order as residential inmates. ${ }^{94}$ In contrast, the reformatories were residential institutions usually for older children who had been convicted of an offence. ${ }^{95}$ In spite of the legislative structure of two types of schools, one designated preventive and the other reformatory in purpose, they evolved into similar institutions with markedly penal regimes. ${ }^{96}$ This was a disciplinary statutory system under which children could be detained for years. The essential point here is that the legislative framework, and the centralising factors associated with it, was in time to alter substantially the character of the original system, first established in Aberdeen : from schools at which attendance was, in theory, voluntary and on a daily basis, to residential institutions where children were detained under court order with severe penalties attached for absconding or helping children to abscond ${ }^{97}$ The contrast with the welfarist ethos of the pre-statutory day industrial schools was stark.

31 Although the disciplinary emphasis mainly originated from outwith Scotland, it is important to recognise that supporters of the reformatory movement in England were far 
from being uniformly punitive in inclination. While the movement was strongly influenced by the disciplinarian model of the Mettray in France, it accommodated a broad spectrum of views. It embraced the humanitarian-philanthropic outlook of the formidable Mary Carpenter with her focus on the child's need for love, realised in the ideal surroundings of her Red Lodge Reformatory for girls in Bristol..$^{98}$ On the other hand, there were also those who bowed to popular demands for retribution, promoting prior imprisonment as a condition of reformatory admission, especially the influential reformatory and industrial school inspector Sydney Turner. ${ }^{99}$ This retributive stance was strongly resisted by both Mary Carpenter and Matthew Davenport Hill but, in a bid to achieve a pragmatic compromise, ultimately the disciplinary approach won the day. ${ }^{100}$ And this outcome was welcomed by landed aristocrats keen to establish reformatory establishments on their country estates as a cheap source of labour. ${ }^{101}$ This was the conflicted and contested context from which the UK legislation emerged and was imposed on the unsuspecting Scottish reformers.

By the 1870s it was very evident that the original ideals promoted by the Scottish reformers were being undermined. Most Scottish industrial schools by then were single sex residential boarding establishments, where the majority were detained under court order. ${ }^{102}$ Watson was determined to restore his central vision of the day industrial school. Despite his advancing years, he was instrumental in a successful campaign to introduce day industrial schools to Glasgow with the result that local legislation was used to provide a statutory basis for day industrial schools much like the original schools set-up in Scottish towns in the 1840s. ${ }^{103}$ But, unfortunately for Watson, Glasgow stood alone in attempting to reclaim the original idea. ${ }^{104}$

Watson's last appearance on the public stage was in 1884 when he gave evidence to a Royal Commission. ${ }^{105}$ Now eighty eight years old, he was persuasive and determined. He used the opportunity to make a strong plea for restoring the first principles upon which his project in Aberdeen had been based. He strongly denounced the residential industrial schools for destroying family ties, adamant that the residential schools should be "utterly abolished." ${ }^{106} \mathrm{He}$ advocated that all certified industrial schools should be converted into day schools, and government aid withdrawn from those that refused to comply. For Watson, as ever, the central focus was not on the reformatories, which he viewed as ancillary to the main operation. The real goal was prevention and that was to be carried on in the day industrial schools which should embrace both the destitute and those with offending behaviour. Watson's evidence demonstrated his disappointment and bewilderment with the way the industrial schools system had departed from the original schools he set up in the 1840s:

I was very sorry to see a child taken away from its parents, and kept in a certified industrial school, who perhaps for three years never saw its parents. I think it was very cruel, and I was very unwilling to break up the family connection. ${ }^{107}$

From the very outset he had been motivated by high humanitarian ideals and had devoted much of his life to the cause of assisting children in trouble. A key element of his philosophy had always been supporting not just the children but their families. This central idea had been eroded by the development of a system which removed children from their families and detained them in institutions for years, undermining familial bonds. 


\section{Conclusion} inspired by Watson? In historical terms it was most important for devising a unique diversionary system, the first major attempt in Britain to create an organised and nationally applied diversionary system for juvenile offenders. This produced a model which formed the basis for the statutory system across the UK. It was also of significance internationally, underpinning a legislative structure which even influenced developments as far afield as Australia. ${ }^{108}$ However, the arrival of a statutory framework in the1850s marked the beginning of a period of transition which changed the Scottish system fundamentally, heralding a gradual departure from the original welfarist ideals of reform.

Ultimately, diversion to residential reformatory and industrial schools had an immense impact upon Scottish children by the close of the nineteenth century. In 1894 the average population of the Scottish reformatory and industrial schools was double that of the daily average adult Scottish prison population. In England, however, the 1894 figures show the average number detained in the schools was slightly less than the daily average adult prison population. ${ }^{109}$ The influential 1896 Report on Reformatory and Industrial Schools recorded that there were about 24,000 children under detention in the 141 industrial schools and 50 reformatories across Britain, with around 5,500 of these detained in 43 Scottish institutions. ${ }^{110}$ This constituted criminalisation of children, especially Scottish children, on a very considerable scale. As scholars such as Mahood, Littlewood, Cox and Cale have all demonstrated in their work, the ethos pervading institutional life for young offenders was highly regulated and disciplined. ${ }^{111}$ The oppressive nature of institutional confinement was also underlined by the 1896 Report which testified to the detrimental psychological effect on children of being detained in institutions run according to repressive regimes. ${ }^{112}$

All of this represented the subversion of the idealistic principles of the original reformers and their pre-statutory legacy founded on principles of compassion, civic co-operation and local cohesion. However, it should be acknowledged that, although there was such a marked divergence from the ideals of the original project, there continued to be definite vestiges of humanitarianism discernible in the Scottish approach. The 1896 Report on Reformatory and Industrial Schools emphasised the "strong repugnance to the imprisonment of children"113. The widespread "aversion felt by the Scottish people" to the idea of child imprisonment ${ }^{114}$ was reflected in the attitude of Scottish judges reluctant to impose the prior period of imprisonment required for reformatory admission. ${ }^{115}$ The continuing current of humanitarianism was also evident in the tendency of Scottish judges to regard the certified schools as a place of refuge for destitute children at a time when there was particularly inadequate alternative social welfare provision for the poor in Scotland ; this accounted for many of the committals to certified schools, particularly to industrial schools where prior imprisonment was avoided. ${ }^{116}$

The 1896 Report recognised the compassionate motivation underlying the over-readiness of judges in Scotland to commit children to the schools. This was an approach based on "a widespread and genuine feeling of commiseration towards the numerous children in the large towns who grow up wild or drift into crime because they are neglected or have bad homes." ${ }^{117}$ Judges were aware of the penal nature of the schools, ${ }^{118}$ but despite the

Crime, Histoire \& Sociétés / Crime, History \& Societies, Vol. 20, n² | 2016 
punitive characteristics, the lack of viable provision for destitute children in Scotland created a situation where they considered they had little choice but to admit children to the schools. ${ }^{119}$ In England considerable numbers of children who were equally eligible for industrial schools were accommodated in workhouse schools, but in Scotland the common practice was to board out pauper children, a system unable to cope with the high level of demand. ${ }^{120}$ The presence of many children in Scottish courts was attributable to this shortage of alternative support mechanisms. This combination of factors provides some explanation for the differences between the statistics on England and Scotland: it indicates that the disparity in the volume of committals can be attributed in part to the approach of the Scottish courts, and the lack of adequate social welfare provision for the poor. All of this suggests a clear link with the welfarist origins of the schools in Scotland, showing that the original spirit of reform left its legacy in certain respects. ${ }^{121}$

What has also emerged strongly from this account is that developments in Scotland did not occur in isolation. There were significant parallels in other jurisdictions struggling to respond to the effects on youth of a potent combination of rapidly changing economic and social factors accompanying the demands of industrialisation. For example, this was evident in the English context where, as King's work on the London Refuge for the Destitute in the early nineteenth century shows, judges in the Old Bailey devised a new diversionary sentencing policy sending young offenders for reformatory training. ${ }^{122}$ This development resonates with the efforts of Scottish judges to create diversionary alternatives to imprisonment for young offenders in Scotland. As we have also seen here in relation to Scotland, and as Susan Margarey's work on London similarly indicates, farreaching changes in criminal justice administration contributed to the increasing criminalisation of children in the nineteenth century, especially in relation to procedure, policing, legislation and sentencing. On the wider international front there were many links too with interaction and channels of communication between reformers in European countries and the US as they exchanged new ideas and approaches towards juvenile offending.

\section{BIBLIOGRAPHY}

\section{REFERENCES}

Angus, M., Sheriff Watson of Aberdeen : the story of his life and work for the young, Aberdeen, D. Wyllie \& Son, 1913.

Barclay, Sheriff of Perth, Juvenile delinquency ; it's causes and cure by a country magistrate, Edinburgh and London, Blackwood \& Sons, 1848.

Barrie, D., Police in the age of improvement, Cullompton, Willan, 2008.

Barrie, D., Broomhall, S., Police courts in nineteenth century Scotland, Farnham, Ashgate, 2014.

Blount T., 'Poor Jo, education, and the problem of juvenile delinquency in Dickens' "Bleak

House"', Modern Philology, 1965, 62, 4, pp. 325-39. 
Cale, M., 'Girls and the perception of sexual danger in the Victorian reformatory system', History, 1993, 78, 253, pp. 201-217.

Carpenter, M., Reformatory schools for the children of the perishing and dangerous classes and for juvenile offenders, London, Gilpin, 1851.

Chambers, W., 'Visit to the Aberdeen schools of industry', Chambers Journal, 1845, 38, p. 305.

Checkland, O., Philanthropy in Victorian Scotland, Edinburgh, Donald, 1980.

Clark, E. A. G., 'The superiority of the 'Scotch System' : Scottish ragged schools and their influence', Scottish Educational Studies, 1977, 9, 1, p. 29-39.

Cox, P., Bad girls in Britain, 1900-1950 : gender, justice, and welfare, Basingstoke, Palgrave, 2002.

Cox, P. \& Shore, H. (Eds.) Becoming delinquent : British and European Youth, 1650-1950,

Aldershot, Ashgate, 2002.

Cruickshank, M., 'The Argyll Commission Report 1865-8 : a landmark in Scottish education', British Journal of Educational Studies, 2010, 15, 2, pp. 133-147.

Davenport Hill, R. \& F., The Recorder of Birmingham : a memoir of Matthew Davenport Hill, London, Macmillan \& Co., 1878.

Dekker, J., The will to change the child : re-education homes for children at risk in nineteenth century Western Europe, Frankfurt, Lang, 2001.

Donzelot, J., The policing of families, Baltimore, John Hopkins University Press, 1997.

Driver, F., 'Discipline without frontiers? Representations of the Mettray reformatory colony in Britain, 1840-1880', Journal of Historical Sociology, 1990, 3, pp. 272-293.

Emsley, C., Crime and society in England, 1750-1900, London, Longman, 2009.

Farmer, L., Criminal law, tradition and legal order : crime and the genius of Scots law, 1747 to the present, Cambridge, Cambridge University Press, 1997.

Follett, R. R., Evangelicalism, penal theory and the politics of criminal law reform in England, 1808-1830, Basingstoke, Palgrave, 2001.

Godfrey, B., Lawrence, P., Crime and justice 1750-1950, Devon, Willan Publishing, 2005.

Guthrie, T., Plea for ragged schools, or, prevention better than cure, Edinburgh, John Elder, 1847.

Hannay, J., 'Lambs to be fed', in Dickens, C., (Ed.) Household Words, 1851, 3, 75, pp. 544-49.

Humphries, J., Childhood and child labour in the British industrial revolution, Cambridge, Cambridge University Press, 2010.

Kelly, C., Criminalisation of children in Scotland 1840-1910, unpublished PhD thesis, University of Glasgow, 2012.

Kelly, C., 'Continuity and change in the history of Scottish juvenile justice', Law, Crime and History, 2016, 6,1, pp. 59-82.

King P., 'The rise of juvenile delinquency in England 1780-1840 : changing patterns of perception and prosecution', Past \& Present, 1998, 160, pp. 116-66.

King, P., Crime and law in England, 1750-1840 : remaking justice from the margins, Cambridge, Cambridge University Press, 2006.

Mahood, L., Policing gender, class and family in Britain, 1800-1940, London, UCL Press, 1995. 
Mahood, L., Littlewood, B., 'The 'vicious' girl and the 'street-corner' boy : sexuality and the gendered delinquent in the Scottish child-saving movement, 1850-1940', Journal of the History of Sexuality, 1994, 4, 4, pp. 549-578.

Manton, J., Mary Carpenter and the children of the streets, London, Heinemann Educational Books, 1976.

Margarey, S., 'The invention of juvenile delinquency in early nineteenth-century England', Labour History, 1978, 34, pp. 11-27.

May, M., 'Innocence and experience : the evolution of the concept of juvenile delinquency in the mid-nineteenth century', Victorian Studies, 1973, 17, 1, pp. 7-29.

Michie, M., An enlightenment Tory in Victorian Scotland : the career of Sir Archibald Alison, East Linton, Tuckwell Press, 1997.

Moore, M., 'Social control or protection of the child ? the debates on the industrial schools Acts 1857-1894', Journal of family history, 2008, 33, 4, pp. 359-387.

Nilan, C. 'Hapless innocence and precocious perversity in the courtroom melodrama : representations of the child criminal in a Paris legal journal, 1830-1848', Journal of Family History, 1997, 22, 3, pp. 251-85.

Prochaska, F., Women and philanthropy in nineteenth century England, Oxford, Oxford University Press, 1980.

Prochaska, F., Christianity and social service in modern Britain, Oxford, Oxford University Press, 2006.

Radzinowicz, L., Hood, R., The emergence of penal policy in Victorian and Edwardian England : a history of English criminal law and its administration from 1750, Volume 5, Oxford, Oxford University Press, 1990.

Ralston, A., The development of reformatory and industrial schools in Scotland, 1832-1872, Scottish Economic and Social History, 1988, 8.1, pp. 40-55.

Ritter, L., Inventing juvenile delinquency and determining its cure (or, how many discourses can you disguise as one construct? in Enders, M., Dupont., B. (Eds.) Policing the lucky country, Hawkins Press, Sydney, 2001.

Sargent, P., Wild arabs and savages : a history of juvenile justice in Ireland, Manchester, Manchester University Press, 2013.

Schlossman, S., Delinquent children : the juvenile reform school in Morris, N. and Rothman, D. (Eds.) The Oxford history of the prison, Oxford, Oxford University Press, 1995.

Shore, H., Artful dodgers : youth and crime in early nineteenth-century London, Woodbridge, Boydell Press, 1999.

Shore, H., 'Reforming the juvenile : gender, justice and the child criminal in nineteenth century England' in Muncie, J., Hughes, G., McLaughlin, E., (Eds.), Youth justice ; critical readings, London, Sage, 2002.

Smout, T. C., A century of the Scottish people 1830-1950, London, Fontana Press, 1997.

Stack, J., 'The provision of reformatory schools, the landed class, and the myth of the superiority of rural life in mid-Victorian England', History of Education, 1979, 8, 1, pp. 33-43.

Thomson, A., Social evils, their causes and cure, London, J. Nisbet \& Co, 1852. 
Watson W., My life, City of Aberdeen Library, unpublished handwritten manuscript, Chapter 1850-1860, (unnumbered pages).

Watson, W. The juvenile vagrant and the industrial school, Aberdeen, George Davidson, 1851.

Watson, W., Chapters on ragged and industrial schools, Edinburgh and London, William Blackwood \& Sons, 1872.

Watson, W., Letter to Glasgow Herald, 3, October, 1874 (a).

Watson, W., Letter to day industrial school campaigners in Glasgow, 16 October, 1874 (b).

Watson, W., Pauperism, vagrancy, crime and industrial education in Aberdeenshire 1840-75, Edinburgh and London, William Blackwood and sons, 1877.

\section{NOTES}

1. Ritter (2001).

2. Young Offenders Committee under the chairmanship of Sir Thomas Molony, 1927, Cmd. 2831, p. 8.

3. Farmer (1997); Barrie (2008) ; Barrie \& Broomhall (2014).

4. Donzelot (1979); Cox (2002); Mahood (2005). On the protective aspects : Moore (2008).

5. Manton (1976).

6. Watson, W., My Life, unpublished handwritten manuscript, City of Aberdeen Library, Chapter 1850-1860.

7. Carpenter (1851).

8. Manton,(1976).

9. Dekker (2001) Note also the obituary of Demetz in Reformatory and Refuge Journal for January 1874 , p. 145 where it is noted that he had been influenced by the agricultural colonies in France and Belgium such as the Rauhe Haus and in 1836 had made exploratory visits to institutions in the US set up by Quakers and Methodists before returning to France to found Mettray. For discussion of Mettray in the US : Schlossman (1995).

10. Driver (1990).

11. Thomson (1852).

12. Nineteenth Report of the Inspector of Reformatory and Industrial Schools, 1876, p. 5.

13. Kelly (2012).

14. Cox \& Shore (2002).

15. Nilan (1997).

16. Cox \& Shore (2002).

17. Magarey (1978).

18. Kelly (2012).

19. Shore (1999, p. 14).

20. May (1973) ; Radzinowicz \& Hood (1990).

21. King (2006).

22. Shore (1999).

23. Farmer (1997); Mahood \& Littlewood (1994); Mahood (2005) ; Ralston (1988).

24. Cox (2002); Cale (1993).

25. Kelly (2012) ; Kelly (2016).

26. Barrie \& Broomhall (2014); Kelly (2016).

27. Michie (1997).

28. Barclay (1848). 
29. Farmer (1997).

30. Letter by Watson to Thomson. Quoted in Angus (1913, p. 59).

31. Watson, W. My Life, Volume I, p. 119 ; Barclay (1848).

32. Guthrie (1847).

33. Kelly (2012).

34. Act of 1841 for repressing juvenile delinquency in the City of Glasgow, 4 and 5 Victoriae, c. 36 ; Ralston (1988) ; Mahood (1995).

35. 1847 Select Committee of the House of Lords appointed to inquire into the execution of the criminal law, especially respecting juvenile offenders and transportation, Paper 447, Volume V11; Kelly (2012).

36. Kelly (2012).

37. HMA $v$ Mary Ann O'Brien, Agnes Wallace and Janet McNaught Brown's Justiciary Reports 2 1844-45, 499.

38. Section 19 related to voluntary requests for admission by a child and did not specify any age requirement. Section 20 applied to children under 12 in a pre-trial situation ; Kelly (2012).

39. Watson's My Life, Volume II, Chapter 1830-40 (unnumbered page of manuscript) ; Angus (1913).

40. Ibid.

41. Follett (2001) ; Checkland (1980); Prochaska (1980); Prochaska (2006).

42. Smout (1997, p. 31).

43. Watson (1872, p. 8) ; Watson (1851, p. 25).

44. Comment made in a letter to Thomson. Quoted in Angus (1913, p. 59).

45. Margarey (1978).

46. Under an Act introduced by Lord Advocate Sir William Rae, 9 Geo. IV c. 29. See chapter three of Farmer (1997).

47. Evidence of Scottish judges appearing before the 1847 Select Committee of the House of Lords to inquire into the execution of the criminal law especially respecting juvenile offenders and transportation. PP. 447, Volume VII.

48. Watson (1877, p. 37).

49. On summary procedure in England see Shore (1999); Shore (2002); Godfrey \& Lawrence (2005) ; Emsley (2009) ; King (1998). Peter King's analysis shows that summary processes in England were linked to increased levels of prosecution of minor offences, and Emsley presents a similar argument.

50. Watson, My Life, Volume 11, Chapter 1830-1840 (unnumbered page of manuscript).

51. Ibid.

52. This local legislation should be viewed in the context of similar legislation in other Scottish towns. David Barrie points out that 'police legislation resulted in stricter regulation and tighter control over street behaviour and the built environment.' Barrie (2008, p. 197).

53. Watson (1872, p. 7).

54. He recommended the appointment of legally trained stipendiary magistrates. atson (1872, p. 40).

55. Watson's My Life, Volume II, Chapter 1830-40 (unnumbered page of manuscript).

56. Watson (1877, p. 40) .

57. Education (Scotland) Act 187235 \& 36 Vict., c. 62.

58. Cruickshank (2010, p. 26-27)..

59. Watson, My Life.

60. Hannay (1851, p. 544).

61. Watson $(1872,6)$.

62. On the economic role of children in the nineteenth century see Humphries (2010). 
63. In his evidence to the 1852 Select Committee on Criminal and Destitute Juveniles, Alexander Thomson, Watson's co-reformer in Aberdeen, stated that the proponents of the schools did not see any distinction between the convicted and the destitute, considering them members of the same class facing the same difficulties in life : Paper 515, Vol VII, p. 301.

64. Watson $(1851,25)$.

65. Watson, My Life; Evidence of Alexander Thomson to 1852 Select Committee on Criminal and destitute Juveniles. Sources do not provide a specific reference for this Act, Thomson referring to a 'local Police Act.'

66. Carpenter (1851, p. 234).

67. Watson, My Life.

68. Angus (1913); Thomson (1852, p. 139); Clark (1977).

69. Chambers (1845).

70. Angus (1913).

71. Carpenter (1851).

72. 1852 Committee on Criminal and Destitute Juveniles, p. 99. She quoted Watson's figures recounting the decline in juvenile vagrancy and delinquency in Aberdeen from 328 vagrants and 61 juvenile delinquents in 1841 to only two vagrants in the area in 1850. For further statistics see evidence of Alexander Thomson to the same select committee at p.292. Thomson, a fellow reformer of Watson's, was a magistrate, chairman of Aberdeen County Prisons Board and author of three texts on industrial schools. He recorded the fall in numbers of children aged 12 and under committed to prison in Aberdeen from 61 in 1841 to 5 in 1851.

73. As noted earlier, Mettray was established in 1840 near Tours, under the auspices of Demetz. See Nineteenth Inspector's Report on Industrial and Reformatory Schools, 1876, p. 5 where Sydney Turner describes how Mettray principles were adapted in the Red Hill reformatory in Surrey; see too Driver (1990).

74. 'is born, not made.'

75. See his letter to Tory M.P. Viscount Adderley, later Lord Norton dated January 11th 1851 quoted in Davenport Hill (1878). Adderley drafted the Bill for the Youthful Offenders Act 1854.

76. Hannay (1851).This article commended the work of Mary Carpenter in England and her recently published work on reformatory schools. This unsigned review of Carpenter's book is attributed to Dickens by Manton (1976) while other commentators suggest James Hannay was the author : Blount (1965).

77. Thomson (1852) : some English towns also adopted aspects of the system.

78. 1852-53 Report of the Select Committee on Criminal and Destitute Children, Paper 674, Volume XX111, p. 41.

79. Ibid. p. 40.

80. Kelly (2012).

81. Manton (1976).

82. Davenport Hill (1878).

83. Kelly (2012).

84. Ibid.

85. Carpenter (1851).

86. For details of the body of nineteenth century legislation applicable to reformatory and industrial schools in Scotland and its application by the courts, see Kelly (2012).

87. The Reformatory Schools (Scotland) Act 1854, 17 \&18 Vict.,c.72-7, or Dunlop's Act, after its author Alexander Murray Dunlop, Liberal MP for Greenock; Ralston (1988).

88. The Youthful Offenders Act 1854 ( 17 \& 18 Vict., c.86). For the chronology of legislative developments in Ireland see Sargent (2013).

89. Watson (1872, p. 17).

90. Watson (1851); Guthrie, T. (1847). 
91. See Guthrie's remarks in Reformatory and Refuge Journal 1861, vol. 1, p. 55 on the importance of prevention. See also Guthrie's comment, comparing giving money to reformatories to giving a man money to buy a wooden leg having refused help him save it. Quoted in Ralston (1988, p. 50).

92. See the annual reports of the Inspector of reformatory and Industrial Schools. For instance, Sydney Turner's 1857 Report at page 7 on the regime in reformatory schools just set up in England under the Youthful Offenders Act 1854 when he described how boys had to work extremely hard: 'digging, trenching, brickmaking and stockkeeping, in all weathers, at all seasons, with the scripture regulation in full force. If a man will not work, neither should he eat.' 93. Ibid.

94. Younger offenders under twelve admitted to industrial schools did not receive convictions.

95. Industrial Schools Act 186629 \& 30 Vict., c.118 ; Reformatory Schools Act 86629 \& 30 Vict., c.117 - this stated that those under 10 should not be sent to a reformatory unless they were previous offenders.

96. 13th Report of the Inpector of Reformatory and Industrial Schools, 1870. See also Report of the Departmental Committee on Reformatory and Industrial Schools, 1896 [C. 8204].

97. Watson (1872, p. 20).

98. Manton (1976).

99. See Sydney Turner's comments at page 10 of Nineteenth report of the inspector of the certified reformatory and industrial schools1876 [C.1534 ].

100. Manton (1976); Davenport Hill (1878).

101. Stack (1979).

102. See Twelfth Report on Reformatory and Industrial Schools, 1868, p. 18. See too Ralston (1988, p. 50).

103. Glasgow Juvenile Delinquency Prevention and Repression Act 1878, 41 \&42 Vict., c. cxxi. Under s.30 of the Act of 1878 certified day feeding schools were introduced in Glasgow ; Watson $(1874, a)$; Watson $(1874$, b) ; Watson (1877) ; Watson,W., My Life.

104. Although Edinburgh introduced a day industrial school (St. John's Hill Day Industrial School) more than twenty years later under the Day Industrial Schools (Scotland) Act 1893, 56 Vict., c.12. 105. 1884 Report of the Commissioners on Reformatories and Industrial Schools [C.3876] [C.3876I].

106. Ibid. p. 442. Kelly (2012).

107. Ibid. p. 413.

108. Ritter (2001, p. 122). In 1866 New South Wales and South Australia adopted legislation on industrial and reformatory schools based on the UK model.

109. The average daily prison population in England and Wales in 1893-4 is given in the Gladstone Report as 18,233. (Report from the Departmental Committee on Prisons, 1895 p. 3.) The average number of children who were inmates in English reformatory and ordinary residential industrial schools in the same year stood at 17,526. See Report of the Departmental Committee on Reformatory and Industrial Schools, 1896, p. 132.

For Scotland the average daily prison population in 1893-4 - a figure of 2,686 - appears in the Sixteenth Annual Report of the Prison Commissioners for Scotland 1894 [C.7470], p. 5. The average number of children who were inmates in Scottish reformatories and residential industrial schools in the same year was 5,476. See Report of the Departmental Committee on Reformatory and Industrial Schools, 1896, p. 132. Note also that the figures of child inmates did not include all of those under order of detention as there were always a number of children out on licence. These figures also do not include children in truant industrial schools (in England) or those in day industrial schools.

110. Report of the Departmental Committee on Reformatory and Industrial Schools, 1896, p. 8 and p. 132.

111. Mahood (1995); Cox (2002); Cale (1993). 
112. 1896 Report, p. 21.

113. 1896 Report, p. 138.

114. 1896 Report, p. 131.

115. Kelly (2012). See 1896 Report (p.138) which explains that the Scottish abhorrence for child imprisonment accounted in part for the high numbers of industrial schools in Scotland compared to reformatories as Scottish judges were reluctant to impose the prior period of imprisonment required for reformatory admission. In situations where young children appeared in court on offence grounds judges might decide not to convict but instead order detention in an industrial school under s.15 of the Industrial Schools Act 1866. This section could be used where a child was under 12 and had no previous convictions. This avoided the need for prior imprisonment. Following the Reformatory Schools Act 1893 (Lord Leigh's Act) prior imprisonment could be dispensed with. The 1896 Report criticized the 'inequality' between Scotland and England in the greater use made by Scottish judges of the optional dispensation of prior imprisonment under the 1893 Act (p. 100). Under the Reformatory Schools Act 1899 prior imprisonment was abolished. This removed the main distinction between reformatory and industrial schools.

116. 1896 Report, p. 138.

117. 1896 Report, p. 138.

118. See the reference by Lord Neaves to the 'penal element' of industrial schools in Wilson $v$ Stirling 18842 Coupar 518. Kelly (2012).

119. Taylor $v$ Tarras $19013 \mathrm{~F} .39$.

120. Report of the Departmental Committee on Reformatory and Industrial Schools, 1896, p. 131, $132 \& 137$.

121. For further analysis of this point see Kelly (2012).

122. King (2006) ; Margarey (1978).

\section{ABSTRACTS}

This article traces the origins and development of fresh diversionary initiatives to respond to juvenile offending in Scottish cities from the mid-nineteenth century. This topic has been somewhat neglected by historians, but the Scottish contribution to juvenile justice reform was significant, both in the UK context and internationally. The paper focuses particularly on the inception and development across Scotland of a network of Day Industrial Schools first introduced in the 1840s. It addresses the changes in Scotland which were brought about by the impact of legislation that ushered in the statutory UK framework governing certified industrial and reformatory schools. The article considers how pressures for uniformity resulted in a marked departure from the welfarist ethos of the reformers undermined the original ideals of reform.

Cet article retrace les origines et le développement de nouvelles initiatives de diversion visant la délinquance juvénile dans les villes écossaises au milieu du XIX ${ }^{\mathrm{e}}$ siècle. Cette question a été quelque peu négligée par les historiens, mais la contribution écossaise à la réforme de la justice des mineurs a été significative aussi bien au Royaume-Uni qu'au plan international. L'article s'intéresse particulièrement à la naissance et au développement, à travers l'Ecosse, dans les années 1840, d'un réseau d'Écoles industrielles d'externat. Il analyse les répercussions en Écosse de changements dans la législation britannique des écoles certifiées d'industrie et de correction 
et la manière dont les pressions à l'uniformisation ont conduit à une déviation marquée par rapport à l'ethos d'assistance des réformateurs et à la fragilisation des idéaux originels de réforme.

\section{AUTHOR}

\section{CHRISTINE KELLY}

A qualified solicitor with a PhD from the University of lasgow, is currently a British Academy Postdoctoral Fellow at the Law School of the University of Glasgow. Her post-doctoral research following her doctoral research on the criminalisation of children in Scotland between 1840 and 1910 - investigates the criminalisation of children in Scotland in the period from 1910 to 1971. The aim is to provide a broader vision of the historical origins of the distinctive Scottish approach to juvenile justice. The author would like to thank Lindsay Farmer for his helpful comments on an earlier version of this paper. - Christine.Kelly@glasgow.ac.uk 